\section{MP-273 精巣腫瘍70例の臨床的検討}

\author{
大阪市立大学 医学部 泌㲾器科 1
}

吉田 直正" 池本 慎一" 成田 敬介”熊田 憲彦" 吉村力勇1” 川嶋秀紀”杉村一誠”仲谷達也"山本啓介”岸本武利”

【目的】15年間に経験した精巣腫瘍精巣腫瘍70例について臨床的 検討を行った。【対象】1995年5月から2000年6月の間に当科で入 院、治療した精巣腫瘍70例（悪性リンパ腫は除外）を対象とした。 【結果之考察】年齢は20歳から74歳 (平均36.8歳)。患側は右 34 例、左36例。七ミノーマ38例 (平均41.4歳)、非七ミノ一 - 32 例 (平均31.4藏)。主訴は、無痛性陰囊内腫瘤／硬結が55例、有痛性 陰囊内腫瘤／硬結が9例、肺転移による呼吸困難等転移巣による 症状か5 5例。停留精巣に発症した症例が2例あった。臨床病期はセ ミノーマでは1期32例、2B期4例、3A期 1 例、3C期 1 例。非七 ミノーマでは1期16例、3B 2 期11例、3C期 5 例。高位精巣摘除 術後の治療は、セミノーマ1期では放射線療法13例、化学療法2例、 survillance17例。非セミノーマ1期では化学療法5例、survillance11 例。2B期以上では大部分の症例で集学的治療が行われた。観察 期間平均63.7力月（5-189力月）で死亡例は非セミノーマ3B2期3 例、3C 期 3 例であった。1期、2期、3A期での死亡例はなかった。 1996年以降2 B 期以上の症例 15 例中9例で PBSCT併用大量化学療 法を行っているが重篤な合併症むなく良好な成績であった。

\section{精果腫痬 臨床統計}

\section{MP-275 精栄胚細胞腫嗙の治療成績}

\section{虎の門病院"}

村田 浩克" 横山正夫”森川弘史”小田裕之"

北原 研" 金村 三樹郎”"小松 秀樹"

【目的】精巣胚細胞腫瘍の治療成績を検討した。【対象】1983年 8月から1999年3月までに虎の門病院で治療した精巣肧細胞腫瘍 65 例66腫瘍を対象とした。【結果】年齢は21〜89 歳 (平均37歳)、 観察期間は1〜203か月（平均69か月）であった。セミノーマ (seminoma) が43腫瘍、非セミノ一 一性胚細胞腫瘍（NSGCT） が23腫瘍であった。臨休病期は1期48例(seminoma:36、NSGCT:12)、 2期9例(seminoma:5、NSGCT:4)、3期9例(seminoma:2、NSGCT:7) であった。治療は全例に高位精巣摘除術を施行した。1期の症例 はseminoma 7例に放射線療法を施行した以外、すべて経過観察 であった。1期では7例に再発を認めた。再発例はすべて経過観察 した症例であった。NSGCT再発例の1例が化学療法之後腹膜りン パ節廓清施行するも再燃し死亡した。Seminomaの2および 3 期の 7例では2期の1例に放射線療法を、残り6例に導入化学療法を施行 した。NSGCTの2および3期の11例には全例導入化学療法を施行 した。この結果CR7例、PR10例、NC1例だった。PRおよびNC例 に残存腫瘍切除術あるいは追加化学療法を施行した。全例NED が得られ、現在癌なし生存6例、転院2例、不明3例だった。【結 論】精巣胚細胞腫瘍の予後は良好であるが、1期の経過観察症例 の再発は17\%あり厳重な経過観察が必要々思われた。

精巣胚細胞腫瘍
MP-274 精果セミノーマの臨床的検討
慶應義塾大学 医学部 泌尿器科"

佐藤 全伯 ${ }^{1}$ 花輪 靖雅" 大東 貴志" 中島 淳" 丸茂 健" 村井 勝"

【目的】当院において治療した精巣セミノーマ症例の臨床的特徽 について検討した。【対象】1980 年より1996 年までに当 院にて治療した精巣セミノーマ症例 64 例を対象とした。結果】 患者年齢は $24 \sim 56$ 歳、平均 36.3 歳、患側は右 36 例、左 28 例であった。臨床病期は 1 期 58 例、2 期 6 例であり、病理 組織はclassic seminoma 55 例、anaplastic seminoma 9 例であ った。T分類では、pT1：49 例、pT2：7 例、pT3：8 例であっ た。全例高位精巣摘除術を施行し、1期では 41 例に放射線療法 を施行し、17例は経過観察とした。2 期については術後化学療 法 (PEB, VBP) を施行し、2 例に後腹膜リンパ節郭清術を施行 した。観察期間において死亡を 1 例認めた。1 期之 2 期では、術 前血中LDH, LDH2, 腫瘍の最大径に有意差を認め、又、腫瘍の 最大径と術前末梢血白血球数、LDH, hCG $\beta$, 自覚症状出現から 受診までの期間に相関を認めた。Logistic回帰による2 期を予測 させる有意の因子は腫瘍の最大径であった。【結論】精巣セミ， 一マは病期に関わらず予後は良好であった。 2 期は 1 期に比べ、 術前血中LDH, LDH2が高值であり、腫瘍の最大径が大きかった。 精巣腫瘰 セミノーマ

\title{
MP-276 日本における精菓腫場の疫学特性
}

\section{足利赤十字病院 泌尿器科1 日高病院 泌尿器科2) 群馬大学 医学部 泌尿器科 ${ }^{3)}$}

中田 誠司"高橋 溥朋" 大竹 伸明2)山中 英壽"

\begin{abstract}
【目的】精巣腫瘍は泌尿器癌の中で多い屯のではないが、すべて の年龄層に発生するという点で重要である。今回、日本の精巣腫 瘍の疫学的特徴について検討した。【方法】「地域がん登録」研 究班の推計値より、1975-94年の全国の精巣腫瘍䍜患率の推計値 を、またわれわれ独自の調查より、1985-94年の群馬県内の精巣 腫廈䍜患率をもとめた。厚生省大臣官房情報部の資料より、197398年の精巣腫瘍の年度別死亡数、年路調整死亡率、年齢別死亡率、 各県別標準化死亡比(SMR)をもと、その特徴について検討し た。櫂患・死亡率の単位は $/ 100$ 万人 $/$ 年とし、年齢調整は世界 人口で行った。【結果】全国の罹患率は、70年代後半から80年代 にかけて増加したが、その後は横ばいであった。群馬県では、全 体として增加傾向であった。全国の死亡数・率は、80年頃より減 少傾向であった。年齢別死亡率の減少率は、小児で最屯高く、2534歳で低かった。各県別では、SMRの高い県は全国に散在して いたが、低い県は西日本に集中していた。【考察】死亡数・率が 減少傾向となったのは、シスプラチンの臨休試験開始時期と一致 した。世界的には、精巣腫瘍の罹患率は白人で高く、黒人、東洋 人では低い。世界的に罹患率は增加傾向で、まれな疾患ではある が啓蒙活動により早期発見、早期治療の努力をすることが重要で ある。
\end{abstract}

啨巣腫掼 疫学 